\title{
Study on the transmissivity characteristics of urban trees in Szeged, Hungary
}

\author{
Ágnes TAKÁCS, Attila KOVÁCS, MÁrton KISS, Ágnes GULYÁS and \\ NoÉmi KÁNTOR ${ }^{1}$
}

\begin{abstract}
This study aims to determine the solar permeability characteristics of some common urban tree species in Hungary and to analyse their shading efficiency in mostly clear sky conditions. The results are based on a measurement-series implemented during the whole vegetation period in 2015. This paper compares different tree species regarding their transmissivity, and looks for differences between different sized tree individuals belonging to the same species. The following order was found among the investigated species regarding their shading-capacity: T. cordata, A. hippocastanum and S. japonica. Additionally, higher transmitted radiation and consequently higher transmisivity values were detected in the case of the smaller investigated A. hippocastanum.
\end{abstract}

Keywords: solar permeability, transmissivity, tree species, Hungary

\section{Introduction}

The global climate change has a considerable impact on the urban population, which makes up more than half of the Earth's population and it is predicted to be two-thirds of the ten billion people by 2050 (UN 2014). Projections of the regional climate models indicate that frequency of the heat waves is likely to be higher in the Carpathian Basin in the forthcoming decades. Indeed, by the last decades of this century a significant increase in the length of heat wave periods can be expected (Pongrácz, R. et al. 2013).

In urban areas significant excess heat is generated by modified surface coverage, complex morphology and anthropogenic heat emission. Compared to the neighbouring rural areas increased air temperature and modified radiation circumstances can be observed in cities; both at micro- and local level (Lelovics, E. et al. 2014; Thorsson, S. et al. 2014). Several investigations demonstrated the impact of these modifications on human thermal comfort and usage of public places (e.g. Kántor, N. and UnGer, J. 2010; ÉGERHÁzI, L.A. et al. 2013). Thermal comfort conditions can be improved by carefully selected construction materials (YANG, X. et al. 2013; ErelL, E. et al. 2014), shading by appropriate building height (BAJSANSKI, I.V. et al. 2015), ensured ventilation (GÁL, T. and UNGER, J. 2009; NG, E. 2009), established water surfaces (Sun, R. and CHEN, L. 2012) as well as by planting effective vegetation (Dimoudi, A. and Nikolopoulou, M. 2003; BOwLER, D.E. et al. 2010).

Urban forests provide a wide range of ecosystem services (from the environmental through the economic to the social benefits) to the city residents (HAASE, D. et al. 2014; Mullaney, J. et al. 2015). One of the most important services from the viewpoint of the altering climatic background is their climate modification effect. Under Central European climate conditions extreme heat stress at the street level is usually the effect of high solar radiation and the resulting high radiation

\footnotetext{
${ }^{1}$ Department of Climatology and Landscape Ecology, University of Szeged. H-6722 Szeged, Egyetem u. 2. Corresponding author: takacsagi@geo.u-szeged.hu
} 
budget of pedestrians (e.g. Kántor, N. and UnGer, J. 2011; LeE, H. et al. 2014). On the one hand, urban tree stands have many positive impacts on the climatic characteristics and air quality in cities at local scale, for example by the sequestration of carbon dioxide and the removal of various air pollutants, and by reducing storm-water runoff (JiM, C.Y. and Chen, W.Y. 2008; Kirnbauer, M.C. et al. 2013; NowAK, D.J. et al. 2013).

On the other hand, vegetation decreases the level of heat stress at micro-scale directly through evapotranspiration and shading (reduction of direct solar radiation). Canopyshading reduces slightly the near-surface air temperature under the trees (ABREU-HARBich, L.V. et al. 2015; Coutrs, A.M. et al. 2016). Compared to air temperature the reduction of the radiation energy income is more important, which entails significant decrease of physiological thermal stress (Gulyás, Á. et al. 2006; KÁnToR, N. et al. 2016). Shading potential of trees depends on species-related characteristics (e.g. crown density, leaf area parameters), age and health status of the tree stands. Large differences can be shown in shading efficiency during the vegetation period, depending on the seasonal foliationdefoliation processes (TAKÁcs, Á. et al. 2016a). Even more important differences may exist among various species (KonARSKA, J. et al. 2014; TAKÁcs, Á. et al. 2015a). There is still a lack of information about the species-specific shading capacity of trees. However, broadening the knowledge about these features would help in designing more effective urban green areas.

In line with this general goal, the aim of our study is to determine the solar permeability characteristics of some of the most common urban tree species in Hungary during the whole vegetation period.

We set the specific targets of this study as follows:

- comparison of different tree species regarding their transmissivity, and

- looking for differences between different sized tree individuals belonging to the same species.
These results can be directly integrated into microclimate modelling and small-scale outdoor thermal stress projection. Thus, our investigations provide indirect help for urban designers and landscape architects in the planning of climate-conscious green infrastructure.

\section{Methods and data}

\section{The city of Szeged}

In order to achieve the above mentioned objectives, a long-term radiation measurementseries was implemented in Szeged. The city is situated in the south-eastern part of Hungary $\left(46^{\circ} \mathrm{N}, 20^{\circ} \mathrm{E}\right)$, and can be characterized with a population of about 162,000 and an urbanized area of about $50 \mathrm{~km}^{2}$. Szeged is spread on a flat area without considerable topographical differences (78-85 $\mathrm{m}$ a.s.1.), which allows small-scale meteorological results to be generalised (Andrade, H. and Vieira, R. 2007).

The region has a warm temperate climate with uniform annual distribution of precipitation. According to the multi-year (19712000) measurement series of the Hungarian Meteorological Service in Szeged the mean annual temperature is $10.6{ }^{\circ} \mathrm{C}$. The daily mean temperature is normally above $10{ }^{\circ} \mathrm{C}$ from April to October; these months correspond to the woody vegetation period, and usually this period of the year is regarded to be the most suitable for outdoor activities. The annual amount of precipitation is 489 $\mathrm{mm}$, while sunshine duration approaches 2000 hours per year (HMS 2015).

\section{Preparations for the radiation measurements}

In Szeged, the first measurement-series on the short-wave radiation-modification effect of urban trees was conducted in 2014. These field surveys lasted from June to November and involved 13 measurement days. Based on the experiences of this 'pilot campaign' (e.g. TAKÁcs, Á. et al. 2015a,b, 2016a), a second meas- 
urement-series was implemented in 2015 with more measurement days. In the course of the second measurement campaign, we conducted simultaneous measurements with two human bio-meteorological stations. One of them was placed under carefully selected urban trees, and the other was placed to an open point of the same study area. The first station stood in the shade while the second instrument was fully exposed to direct solar radiation during the measurement period.

Before the micrometeorological measurement campaign, thorough field surveys were conducted in Szeged aiming to select the appropriate study locations and trees. We sought to represent those species that are frequently planted in Hungarian towns as street or park trees. The main criteria were to find healthy, adult, single shade tree specimens without the disturbing effect of other landscape elements (SHAHIDAN, M.F. et al. 2010; Konarska, J. et al. 2014; Abreu-Harbich, L.V. et al. 2015), in order to ensure that other trees or buildings do not influence the recorded parameters. We selected trees that stood in a park or a square with considerable amount of open sunny locations in order to facilitate the nearby 'sunlit' measurements.

Finally, five specimens that met the above criteria were selected for the purpose of our investigations:

- one Tilia cordata (small-leaved linden),

- one Sophora japonica (pagoda tree),

- one Celtis occidentalis (common hackberry), and

- two Aesculus hippocastanums (horse chestnut).

The study areas comprised four recreational places in Szeged (Mátyás square, Búvár lake, Rákóczi square and Kodály square) (Figure 1).

It should be highlighted that the two $A$. hippocastanums have different dimensional characteristics. One of them has larger full height and canopy diameter while slightly lower trunk height. (This specimen is called hereinafter as 'larger' and abbreviated as ' $l$ ', while the other specimen is denominated as 'smaller' or 's'.) Regarding full height, trunk height and canopy diameter, the $T$. cordata has comparable dimensions with the two A. hippocastanums. However, the selected $S$. japonica and C. occidentalis have smaller full height but larger canopy diameter than the other species (Table 1).

\section{Details of the radiation measurements in 2015}

The data collection was carried out with two special human bio-meteorological stations, both of them equipped with sensors measuring the same meteorological variables in one-minute resolution. Each day, the instruments were installed 10-20 min. prior to the dedicated measurement period in order to allow sensors to stabilize. The stations allow us to record all meteorological parameters that influence the human energy budget (TAKÁcs, Á. et al. 2016b). However, since this study is focusing on the shading capacity of trees, we analyze the changes of one parameter only. This parameter is the global radiation $(G)$, which involves the short-wave radiation flux densities from the upper hemisphere and includes both direct and diffuse parts of the solar radiation:

$G_{\text {trans }}\left[\mathrm{W} / \mathrm{m}^{2}\right]$ is the transmitted solar radiation measured under the selected urban trees, at a distance of two meters on the northern side of the tree trunk,

$G_{a c t}\left[\mathrm{~W} / \mathrm{m}^{2}\right]$ is the actual value of global radiation measured at the nearby open site.

Transmissivity - a dimensionless value ranging from 0 to 1 - was calculated as the ratio of the measured $G$ values:

$$
\text { Transmissivity }=\frac{G_{\text {trans }}}{G_{a c t}}
$$

$G$ data were recorded by Kipp \& Zonen radiometers, i.e. by the upper pyranometers of a CNR 1-type net radiometer in the case of the shaded station and of a CNR 4-type in the case of the sunlit instrument. Using telescopic legs, the sensors were placed at $1.1 \mathrm{~m}$ height above ground level. This height corresponds to the centre of gravity of a standing 


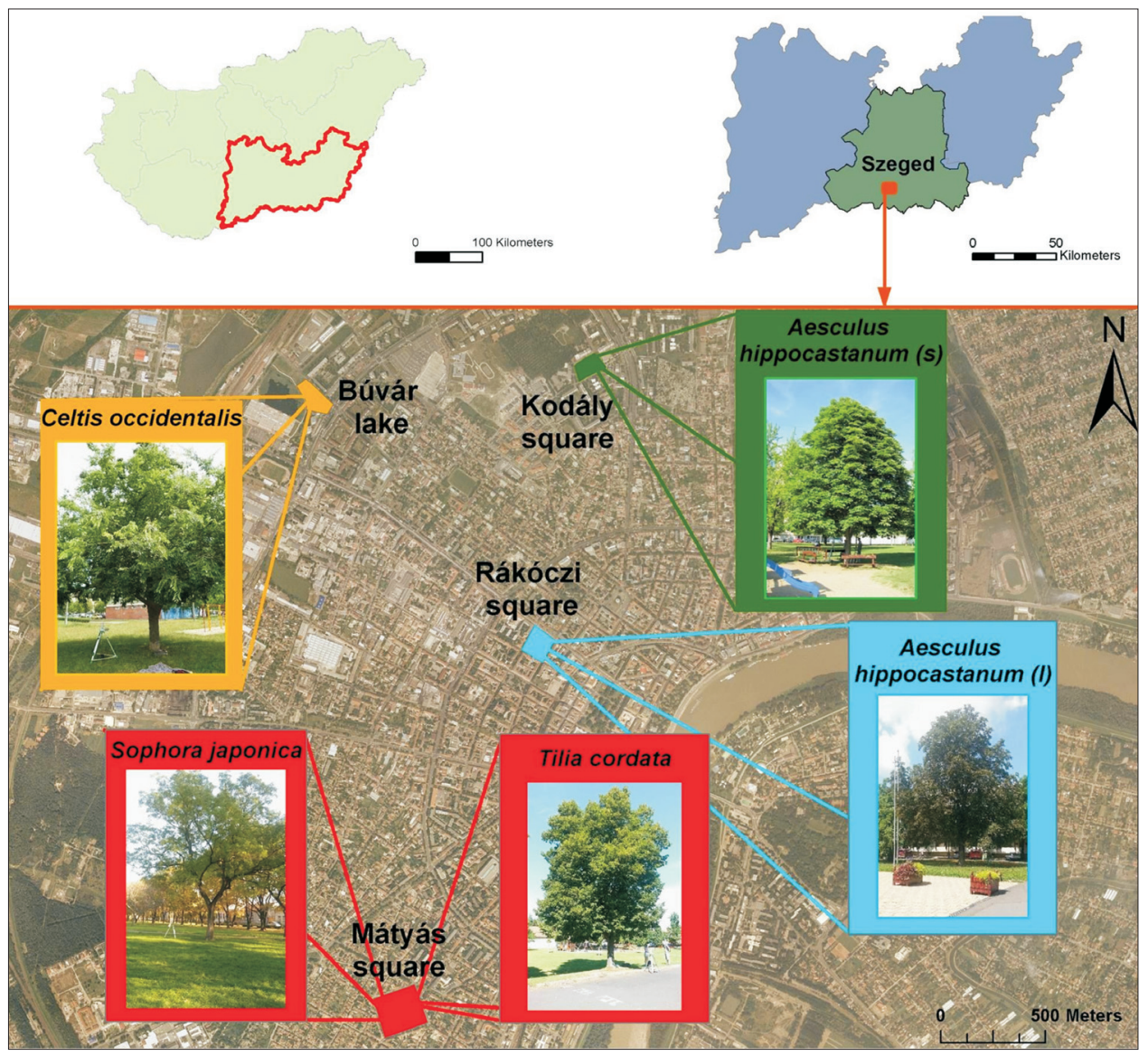

Fig. 1. Investigated trees and their location in the city of Szeged, Hungary

Table 1. Main dimensional attributes of the investigated urban trees

\begin{tabular}{l|c|c|c|c|c}
\hline \multicolumn{1}{c|}{ Species } & $\begin{array}{c}\text { Aesculus } \\
\text { hippocastanum }(l)\end{array}$ & $\begin{array}{c}\text { Aesculus } \\
\text { hippocastanum (s) }\end{array}$ & $\begin{array}{c}\text { Tilia } \\
\text { cordata }\end{array}$ & $\begin{array}{c}\text { Sophora } \\
\text { japonica }\end{array}$ & $\begin{array}{c}\text { Celtis } \\
\text { occidentalis }\end{array}$ \\
\hline Full height, $\mathrm{m}$ & 15.0 & 13.5 & 15.5 & 12.0 & 9.0 \\
Trunk height, $\mathrm{m}$ & 2.0 & 2.5 & 2.5 & 3.0 & 1.8 \\
Canopy diameter, $\mathrm{m}$ & 10.0 & 9.0 & 9.0 & 12.0 & 14.0 \\
Trunk diameter, $\mathrm{cm}$ & 78.0 & 57.0 & 70.5 & 75.0 & 70.0 \\
\hline
\end{tabular}

European man, the most frequently applied standard subject in outdoor thermal comfort investigations (MAYER, H. et al. 2008; LeE, H. et al. 2013, 2014). Following the instructions of the manual of the net radiometers, we took special care about the horizontal levelling and their orientation to South.

The comparability of the two pyranometers was tested on a cloudy and a totally clear summer day. In the frame of the test, both equipments were placed to the sun. The average differences between the measured global radiation values were only 10.14 and $3.8 \mathrm{~W} / \mathrm{m}^{2}$ on the two days, respectively. All data considered, the differences ranged from -35 to $50 \mathrm{~W} / \mathrm{m}^{2}$ and did not exceed $25 \mathrm{~W} / \mathrm{m}^{2}$ in absolute value in more than $80 \%$ of the cases. 
The radiation measurements lasted from April to October in 2015 and consisted of 36 measurement days, i.e. the campaign covered the whole vegetation period (Table 2).

\section{Data analysis}

This study focuses on the differences regarding the shading-capacity of the investigated trees. For studying the inter-species differences we selected the T. cordata, the S. japonica and the smaller A. hippocastanum. Then we compared the two A. hippocastanums in order to examine the impact of mere dimensional inequalities. For these two analyses 20 days were selected from the total 36 measurement days (Table 2) based on the following aspects.

Inter-species differences were examined only in the hottest period of the year (summer). This comparison was based on the data of days when similar global radiation background was found. (Days close to each other were selected to improve the accuracy of comparison.) One of the main criteria was to select such day-combinations that can be characterized with the least disturbing effect of clouds.

In the case of the larger and smaller $A$. hippocastanum, the comparison period covered almost the whole measurement period (Table 2).
Only three days were excluded: the sole day in April, as well as two days in late autumn due to the disturbing effect of other trees and buildings caused by the low sun elevation. The two A. hippocastanum specimens were monitored on consecutive days in almost every case in order to ensure as similar conditions regarding the potential global radiation background as possible. Data analyses were performed within the statistical software SPSS.

\section{Results}

\section{Inter-species differences}

One of the specific goal of the study was to explore differences in the solar permeability of different shade tree species during the hottest period of the year. The selected trees include the smaller $A$. hippocastanum, the T. cordata and the S. japonica; each of them represented with four measurement days in summer (Table 2). The smaller individual was selected from the two A. hippocastanums for the purpose of this comparison since it was monitored more frequently under favorable sky conditions.

Figure 2 illustrates the daily curves of $G_{a c t}$ $G_{\text {trans }}$ and transmissivity, while Table 3 shows

Table 2. Measurement days in 2015 under the selected tree specimens*

\begin{tabular}{c|c|c|c|c}
\hline $\begin{array}{c}\text { Aesculus } \\
\text { hippocastanum }(l)\end{array}$ & $\begin{array}{c}\text { Aesculus } \\
\text { hippocastanum }(s)\end{array}$ & $\begin{array}{c}\text { Tilia } \\
\text { cordata }\end{array}$ & $\begin{array}{c}\text { Sophora } \\
\text { japonica }\end{array}$ & $\begin{array}{c}\text { Celtis } \\
\text { occidentalis }\end{array}$ \\
\hline- & 23-Apr-2015 & 16-Apr-2015 & - \\
\hline 12-May-2015 & 18-May-2015 & 11-May-2015 & 07-May-2015 & 06-May-2015 \\
\hline 01-Jun-2015 & 02-Jun-2015 & 30-May-2015 & 29-May-2015 & $\begin{array}{c}\text { 28-May-2015 } \\
\text { 03-Jun-2015 }\end{array}$ \\
\hline 02-Jul-2015 & 01-Jul-2015 & 03-Jul-2015 & 06-Jul-2015 & 05-Jul-2015 \\
\hline 21-Jul-2015 & 22-Jul-2015 & 01-Aug-2015 & 06-Aug-2015 & 23-Jul-2015 \\
\hline 27-Aug-2015 & 28-Aug-2015 & 31-Aug-2015 & 01-Sep-2015 & 29-Aug-2015 \\
\hline 01-Oct-2015 & 02-Oct-2015 & - & - & 03-Oct-2015 \\
\hline 28-Oct-2015 & 29-Oct-2015 & 26-Oct-2015 & 27-Oct-2015 & 30-Oct-2015 \\
\hline
\end{tabular}

*Coloured days were selected for the analyses. 


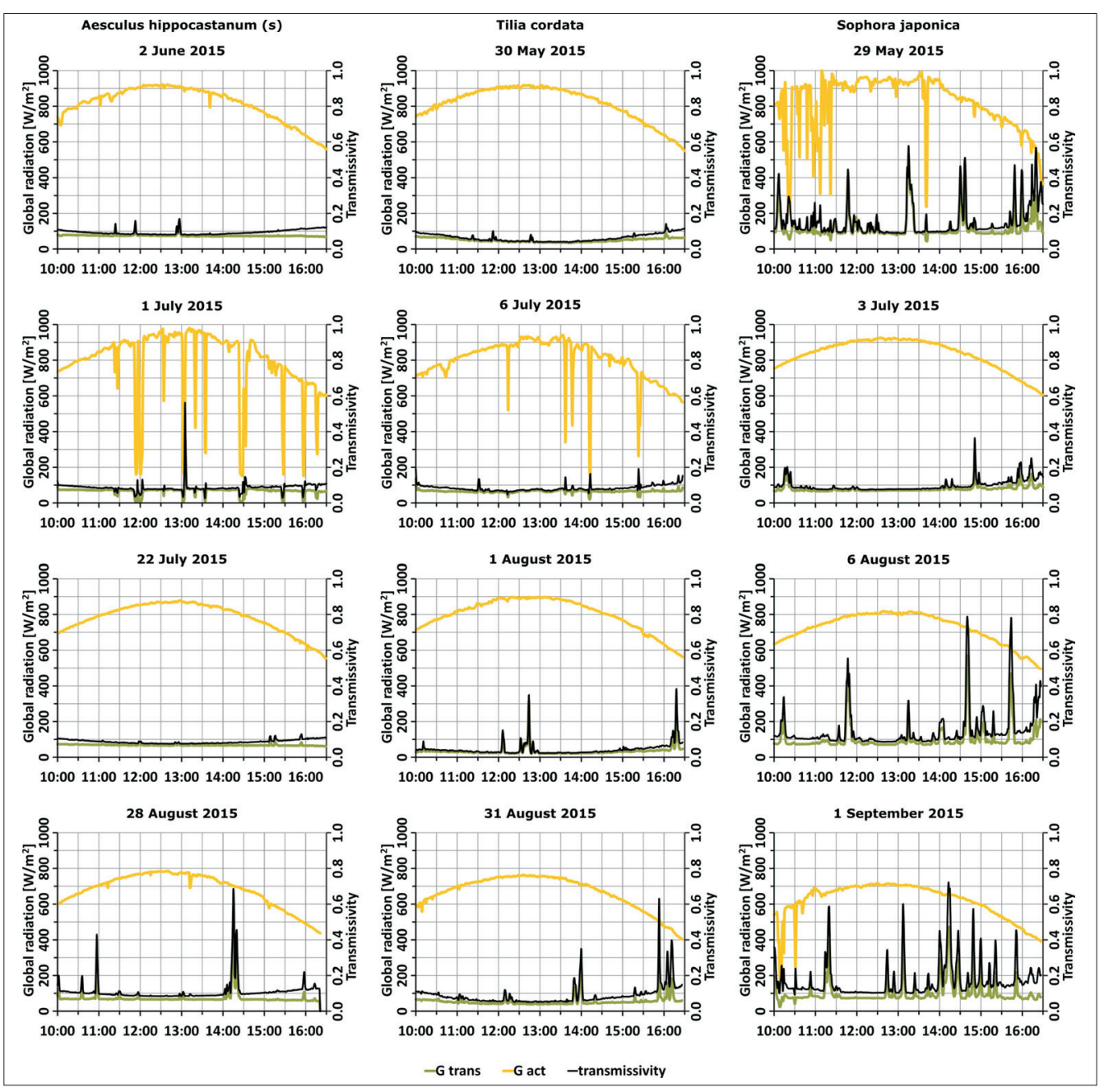

Fig. 2. Differences in solar permeability through the foliage of three different species: the smaller Aesculus hippocastanum (s), Tilia cordata and Sophora japonica. Time is in CET; $G_{\text {trans }}=$ transmitted radiation; $G_{a c t}=$ actual value of global radiation

the corresponding descriptive statistics of daily transmissivity values. It is important to note that the statistic tables are based on the data of 'sunny minutes' only, aiming to get rid of the disturbing effect of clouds, which caused sometimes sharp 'apparent transmissivity increases': see for example the cases of July 1 (around 12 a.m. and 1 p.m.) as well as July 6 (around 1.40, 2.10 and 3.20 p.m.) when sharp decreases of $G_{a c t}$ coinciding with moderate decreases of $G_{\text {trans }}^{\text {act }}$ caused smaller or greater jumps in the transmissivity curve. Clear sky conditions, however, can be characterized with smooth, bell-shaped $G_{a c t}$ curves, and in these circumstances the sharp increases in $G_{\text {trans }}$ result in real jumps of transmissivity.

A slight temporal tendency can be observed within the summer period for all species, i.e. the lowest transmissivities were calculated for early or late July, while the highest ones were obtained at the end of 
Table 3. Basic descriptive statistics regarding the transmissivity values of the smaller Aesculus hippocastanum (A. $h$. (s)), Sophora japonica (S. j.) and Tilia cordata (T. c.) on their investigation days*

\begin{tabular}{|c|c|c|c|c|c|c|c|}
\hline Tree & Date & $\mathrm{N}$ & Stand. Dev. & Min. & Median & Mean & Max. \\
\hline $\begin{array}{l}\text { S.j. } \\
\text { T. c. } \\
\text { A. h. (s) }\end{array}$ & $\begin{array}{l}\text { 29-May-2015 } \\
\text { 30-May-2015 } \\
\text { 02-Jun-2015 }\end{array}$ & $\begin{array}{l}345 \\
389 \\
389\end{array}$ & $\begin{array}{l}0.097 \\
0.021 \\
0.013 \\
\end{array}$ & $\begin{array}{l}0.086 \\
0.038 \\
0.079\end{array}$ & $\begin{array}{l}0.113 \\
0.057 \\
0.090 \\
\end{array}$ & $\begin{array}{l}0.154 \\
0.063 \\
0.094 \\
\end{array}$ & $\begin{array}{l}0.578 \\
0.141 \\
0.169 \\
\end{array}$ \\
\hline $\begin{array}{l}\text { A.h. (s) } \\
\text { S. j. } \\
\text { T. c. }\end{array}$ & $\begin{array}{l}\text { 01-Jul-2015 } \\
\text { 03-Jul-2015 } \\
\text { 06-Jul-2015 }\end{array}$ & $\begin{array}{l}350 \\
388 \\
373\end{array}$ & $\begin{array}{l}0.014 \\
0.034 \\
0.016\end{array}$ & $\begin{array}{l}0.057 \\
0.074 \\
0.047\end{array}$ & $\begin{array}{l}0.085 \\
0.086 \\
0.079\end{array}$ & $\begin{array}{l}0.087 \\
0.099 \\
0.083\end{array}$ & $\begin{array}{l}0.269 \\
0.364 \\
0.191\end{array}$ \\
\hline $\begin{array}{l}\text { A. h. (s) } \\
\text { T. c. } \\
\text { S.j. }\end{array}$ & $\begin{array}{l}\text { 22-Jul-2015 } \\
\text { 01-Aug-2015 } \\
\text { 06-Aug-2015 }\end{array}$ & $\begin{array}{l}390 \\
388 \\
388 \\
\end{array}$ & $\begin{array}{l}0.011 \\
0.036 \\
0.107 \\
\end{array}$ & $\begin{array}{l}0.075 \\
0.022 \\
0.086 \\
\end{array}$ & $\begin{array}{l}0.084 \\
0.035 \\
0.113 \\
\end{array}$ & $\begin{array}{l}0.088 \\
0.044 \\
0.149 \\
\end{array}$ & $\begin{array}{l}0.128 \\
0.386 \\
0.785 \\
\end{array}$ \\
\hline $\begin{array}{l}\text { A. h. (s) } \\
\text { T. c. } \\
\text { S.j. }\end{array}$ & $\begin{array}{l}\text { 28-Aug-2015 } \\
\text { 31-Aug-2015 } \\
\text { 01-Sep-2015 }\end{array}$ & $\begin{array}{l}381 \\
387 \\
376\end{array}$ & $\begin{array}{l}0.059 \\
0.056 \\
0.104 \\
\end{array}$ & $\begin{array}{l}0.083 \\
0.051 \\
0.101\end{array}$ & $\begin{array}{l}0.099 \\
0.073 \\
0.133\end{array}$ & $\begin{array}{l}0.111 \\
0.088 \\
0.172 \\
\end{array}$ & $\begin{array}{l}0.686 \\
0.634 \\
0.722 \\
\end{array}$ \\
\hline
\end{tabular}

*The statistics are based on the data of sunny minutes $(\mathrm{N})$ only.

August (Figure 2, Table 3). S. japonica had the highest transmissivity in all measurement periods, generally exceeding 0.1 , except for early July. According to the obtained transmissivity values, $T$. cordata can be considered to be the most effective shade tree species in the investigation period. In early August, its transmissivity values scattered around 0.04 and for most of the day its $G_{\text {trans }}$ values were below $50 \mathrm{~W} / \mathrm{m}^{2}$ (Figure 2). Even at the end of August when the compared trees showed the highest solar permeability within summer we measured still fairly low transmissivities, being lower than 0.1 (median: 0.073, mean: 0.088) (Figure 2, Table 3). Thus, we can set a shading-capacity sequence among the investigated species as follows: T. cordata, $A$. hippocastanum and S. japonica.

Standard deviation of transmissivity of $S$. japonica approached or exceeded 0.1 in threequarters of the cases $(0.097,0.107$ and 0.104 in May, August and September, respectively), while A. hippocastanum's transmissivity values had the lowest standard deviation (they were between 0.011-0.014 in three days) (Table 3).

There is an additional feature regarding the transmissivity of lonely shade trees that can be noticed on the charts of Figure 2, especially, in the cases of T. cordata: see that the transmissivity values tend to be the lowest when the global radiation reaches its daily maximum. On the other hand, during the earliest and latest hours of the measurement period, when the bell-shaped $G_{a c t}$ curve reaches its lowest values, the transmissivity shows a slight but monotonic increase. That is, the rate of decline in global radiation is not followed by the decrase in transmitted radiation. In fact, $G_{\text {trans }}$ keeps its level or may be even greater at lower sun elevations because more diffuse radiation may reach the 'shaded pyranometer' from lateral directions at these situations.

\section{Dimensional differences}

Now we are looking for the effectiveness of solar radiation reduction in the light of pure size differences. For this purpose we consider the two A. hippocastanum specimens with different dimensional attributes. The daily courses of actual global radiation, transmitted radiation as well as the transmissivity values are depicted on Figure 3. Besides, Table 4 contains the main descripitive statistics regarding the daily transmissivity values. It should be highlighted again that only those minutes were considered for these statistics that were free from the effects of clouds (see the different case numbers $-N$ - in the table).

The daily curves of actual global radiation reflect the normal seasonal differences occurring in our region: $G_{a c t}$ approached 1,000 W/ $\mathrm{m}^{2}$ in early July while it remained below 700 $\mathrm{W} / \mathrm{m}^{2}$ during the autumn days (Figure 3 ). 

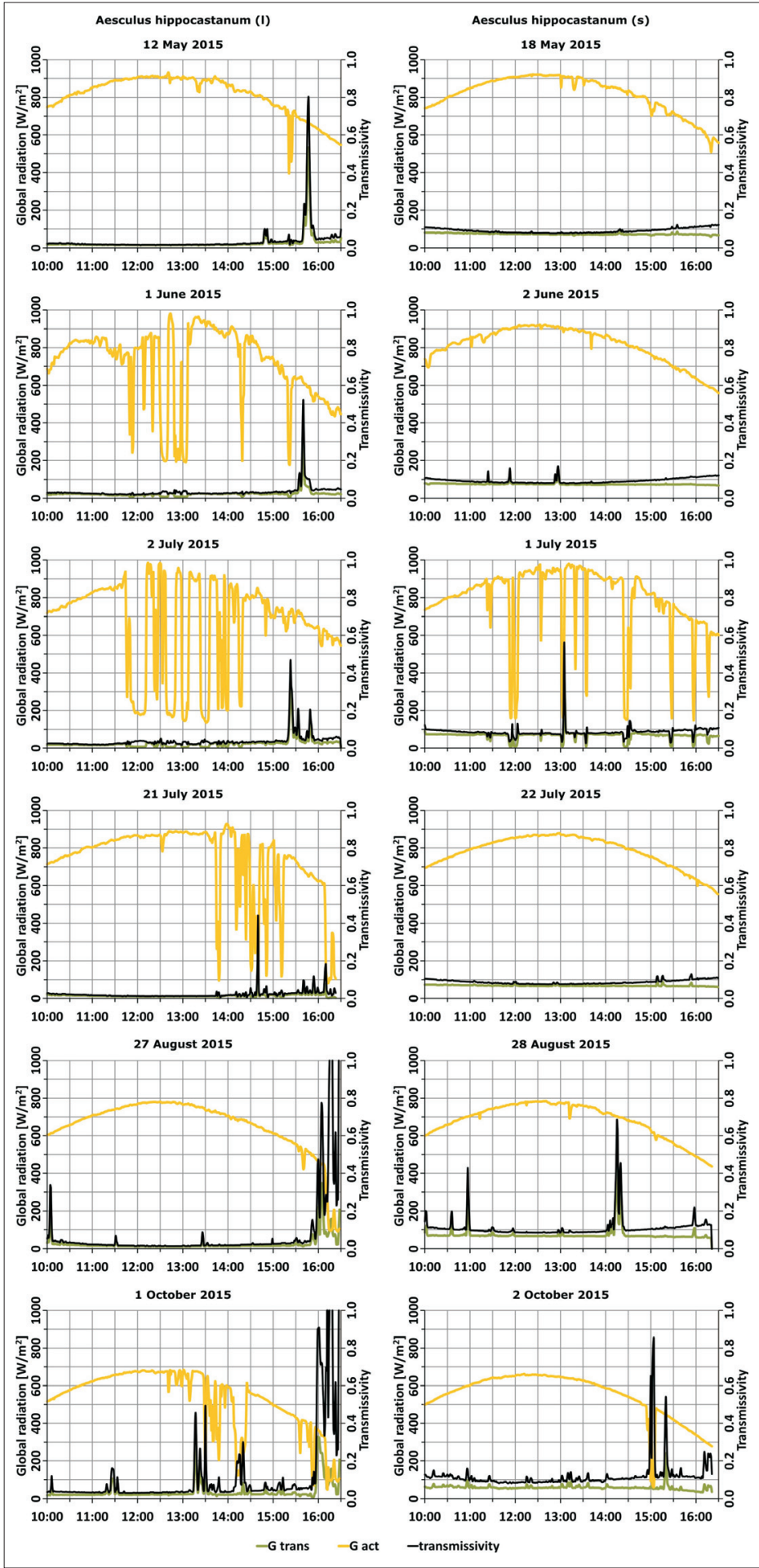

Different dimensional characteristics of the investigated specimens affected obviously the solar permeability of the tree crown in the case of each day-pair. Namely, higher transmitted radiation and consequently higher transmisivity values were detected in the case of the smaller A. hippocastanum (Figure 3). The descriptive statistics in Table 4 confirm this statement: all median and mean transmissivity values were higher under the smaller individual.

The solar permeability showed a decreasing order along the spring and summer months in the case of both trees. In the case of the larger specimen the transmissivity values fell in the range of 0.02-0.04 in spring and they were below 0.02 in mid-summer, while they declined from 0.09 to 0.085 concerning the smaller tree. After that, the transmissivity values started to increase and they peaked in October when the values of the smaller individual often exceeded 0.1 (Figure 3, Table 4). This phenomenon can be explained obviously by the seasonal foliation status of the trees.

Fig. 3. Differences in solar permeability of the larger $(l)$ and smaller (s) Aesculus hippocastanum from spring to autumn. Time is in CET; $G_{\text {trans }}=$ transmitted radiation; $G_{a c t}=$ actual value of global radiation 
Table 4. Basic descriptive statistics regarding the transmissivity of the larger (l) and smaller (s) Aesculus hippocastanum (A.h.) trees*

\begin{tabular}{l|l|l|c|c|c|c|c}
\hline \multicolumn{1}{c|}{ Tree } & \multicolumn{1}{|c|}{ Date } & $\mathrm{N}$ & Stan. Dev. & Min. & Median & Mean & Max. \\
\hline$A . h .(l)$ & 12-May-2015 & 371 & 0.075 & 0.014 & 0.020 & 0.037 & 0.801 \\
A. $h .(s)$ & 18-May-2015 & 360 & 0.012 & 0.077 & 0.087 & 0.091 & 0.122 \\
$A . h .(l)$ & 01-Jun-2015 & 316 & 0.042 & 0.018 & 0.028 & 0.037 & 0.523 \\
\hline$A . h .(s)$ & 02-Jun-2015 & 389 & 0.013 & 0.079 & 0.090 & 0.094 & 0.169 \\
$A . h .(s)$ & 01-Jul-2015 & 350 & 0.014 & 0.057 & 0.085 & 0.087 & 0.269 \\
$A . h .(l)$ & 02-Jul-2015 & 301 & 0.045 & 0.017 & 0.029 & 0.040 & 0.468 \\
\hline$A . h .(l)$ & 21-Jul-2015 & 321 & 0.013 & 0.007 & 0.016 & 0.019 & 0.118 \\
$A . h .(s)$ & 22-Jul-2015 & 390 & 0.011 & 0.075 & 0.084 & 0.088 & 0.128 \\
$A . h .(l)$ & 27-Aug-2015 & 369 & 0.081 & 0.014 & 0.022 & 0.039 & 0.775 \\
\hline$A . h .(s)$ & 28-Aug-2015 & 381 & 0.059 & 0.083 & 0.099 & 0.111 & 0.686 \\
$A . h .(l)$ & 01-Oct-2015 & 342 & 0.130 & 0.030 & 0.037 & 0.074 & 0.908 \\
$A . h .(s)$ & 02-Oct-2015 & 372 & 0.039 & 0.082 & 0.104 & 0.111 & 0.542 \\
\hline
\end{tabular}

*The statistics are based on the data of sunny minutes $(\mathrm{N})$ only.

The decline in $G_{a c t}$ values on cloudy days implies relatively smaller increase in tranmissivity values in summer when transmissivity values are already the lowest. We found comparably high transmissivity values in the case of the larger A. hippocastanum at the end of the daily measurement period on the late summer day and the autumn measurement day (Figure 3). Accordingly, we got remarkably different median and mean values on these days (median of 0.022 and mean of 0.039 on 27 August, and median of 0.037 and mean of 0.074 on 1 October; Table 4). Comparing the transmissivity of the two tree individuals based on their daily medians, we found considerably higher values in the case of the smaller specimen (Table 4), that is, even in the case of adult trees, the dimensional characteristics have a great impact on the shading capacity.

Concerning the differences in standard deviation $(S D)$ of the two specimens, almost the same $S D$ values were observed in late July (0.013 and 0.011; Table 4). At this time of the year the foliage is expected to be fully developed and most dense. In other days, however, the larger individual had considerably higher $S D$. The reason for this can be attributed to the 'regular jump' of the larger tree's transmissivity in the afternoon, which was caused by canopy-structural characteristics (a greater broken off branch).

\section{Discussion and outlook}

Planting and maintaining urban tree stands is one of the most obvious ways to fight against heat stress and to create comfortable outdoor places in urban areas. Vegetation mitigates the level of thermal stress most effectively via shading, i.e. by reduction of incoming short-wave radiation (KoNARSKA, J. et al. 2014; KÁNTOR, N. et al. 2016; TAKÁCs, Á. et al. 2016a,b). We presented the results of a long-term field measurement series, which covered the whole vegetation period. In line with the primary goal of the study, the analyses focused on the shading capacity of single, mature trees belonging to those species that are frequently planted in Hungarian towns as street or park trees. As a measure, dimensionless transmissivity values were calculated. We were looking for inter-species differences, and examined the effect of dimensional differences on the shading capacity of mature trees. The resulted graphs (Figures 2 and 3) revealed that transmissivity is sensitive to the background sky conditions, especially to the rapid changes of sunny and cloudy periods. Therefore, we performed the main descriptive analyses on the basis of clear sky condition values only (Table 3 and 4).

Shading efficiency of urban trees and its variation among different species and seasons can provide useful information with 
regards to climate sensitive planning and modelling of outdoor thermal comfort in cities (KonARsKa, J. et al. 2014). However, there is still a lack of information in experimental transmissivity data. As an international comparison, Figure 4 summarizes the outcomes of the available transmissivity studies that have been carried out in different geographical areas. The displayed mean transmissivity values were based on clear (or mostly clear) measurement days in summer - or at least on those days when the investigated trees were fully foliated. (The mean values of the present study were based on the days in Table 3). Figure 4 illustrates great inter-species differences, and evinces the effective shading of Tilia and Aesculus species.

Besides, similarily to previous investigations (e.g. Cantón, M.A. et al. 1994; Konarska, J. et al. 2014; TAKÁcs, Á. et al. 2015a), this study revealed significant annual differences in transmissivity (Figure 3), which depend on the species-specific foliation-defoliation cycle. Due to these findings, application of monthly, or at least seasonally transmissivity values would be required in radiation and bio-climate modelling.

Figure 5 offers a graphical summary about the main findings of this study, including the disturbing impact of clouds on the calculated transmissivity values, the dimension-related effects and the inter-species differences. The chart-montage shows the daily graphs of $S$. japonica, T. cordata and the two A. hippocastanums based on the data of four nearby summer days.

The effect of clouds is clearly reflected in the higher and most variable transmitted radiation and thus transmissivity values during the afternoon hours of 21 July (Figure 5, a). One reason for that may be that the ratio of diffuse radiation (as part of the global radiation) increases at the expense of direct radiation during cloudy conditions. The foliage, however, is more effective regarding the interception of direct radiation than diffuse radiation (CANTón, M.A. et al. 1994; KONARSKA, J. et al. 2014). In cloudy conditions, the actual value of $G$ may drop because of the decrease of direct radiation, however, the diffuse part that is less effectively shielded by tree crown is almost the same. This may result in much greater decrease in $G_{a c t}$ than in $G_{\text {trans' }}$ thus an increase in transmissivity.

The frequency of temporary transmittance of direct radiation through the foliage is a species-related attribute depending on canopy-structural characteristics (SHAHIDAN, M.F. et al. 2010). Of course, if we put species-specific characteristics in the focus of the inves-

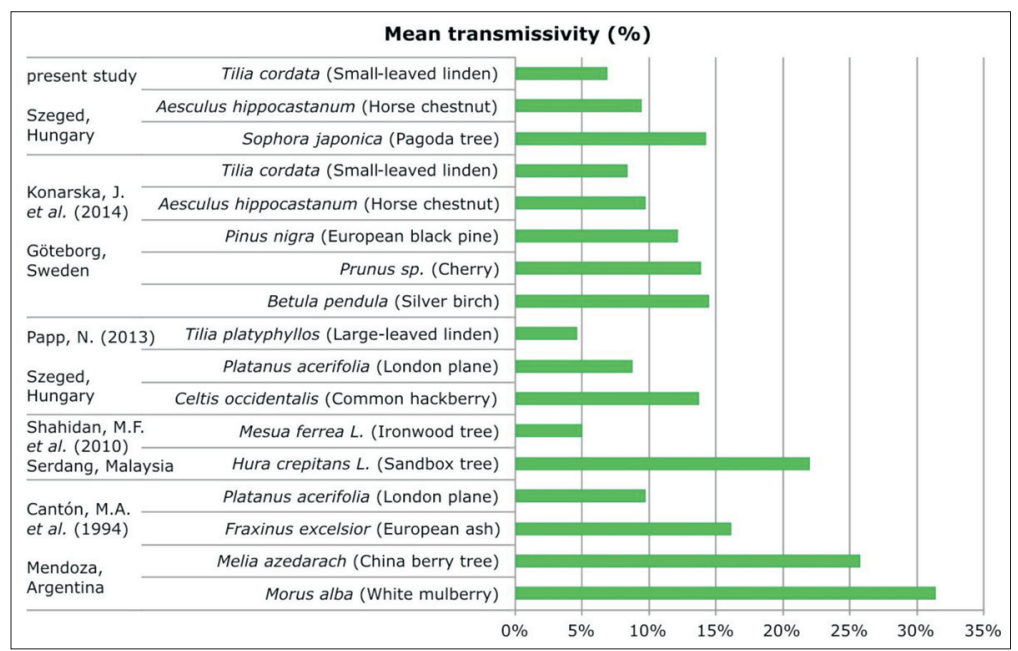

Fig. 4. Comparison of mean transmissivity values found in different experimental studies 


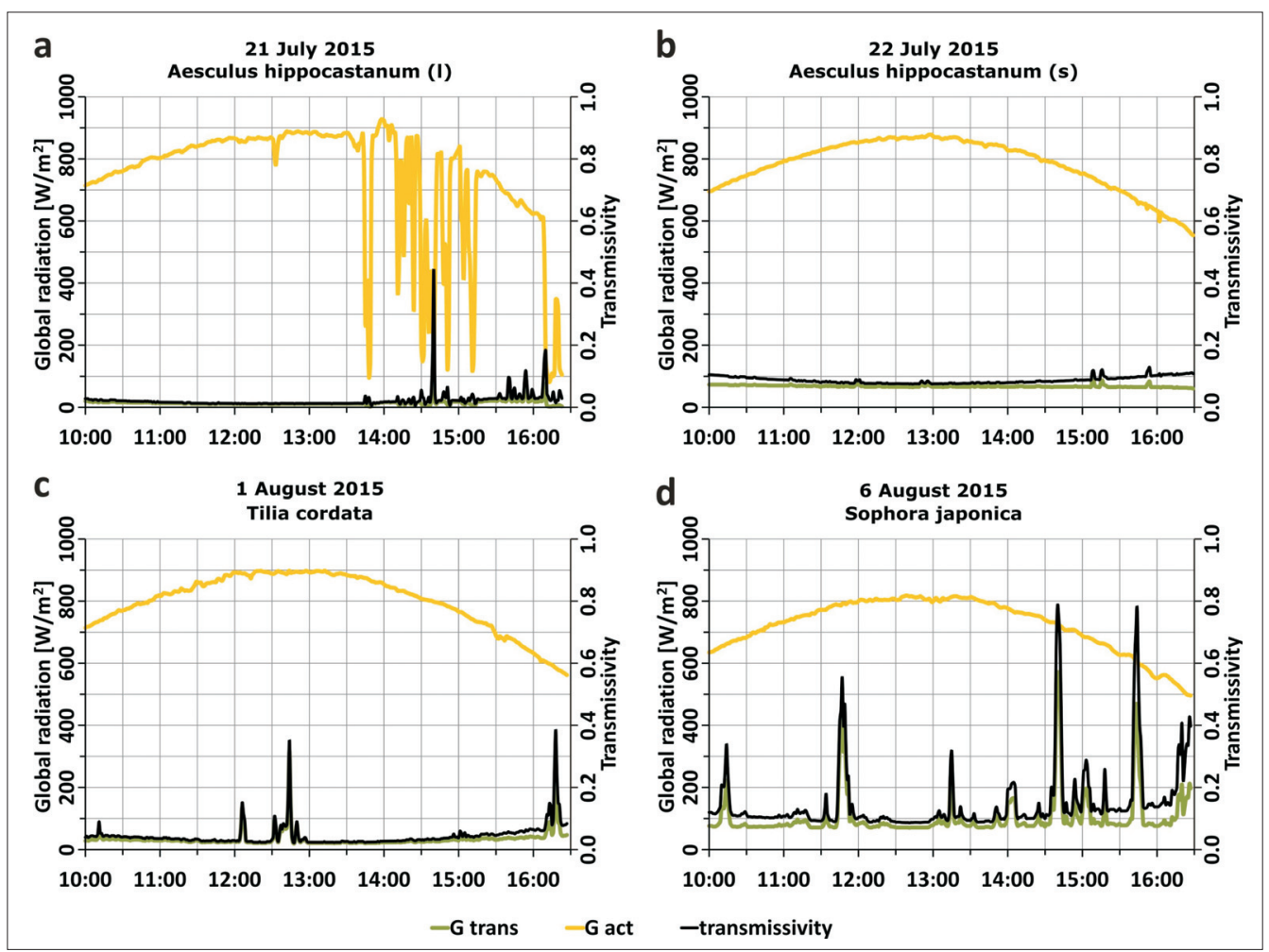

Fig. 5. Transmissivity and the short-wave radiation from the upper hemisphere measured under different shade-trees as well as in a nearby open point. Time is in CET; $G_{\text {trans }}=$ transmitted radiation; $G_{a c t}=$ actual value of global radiation

tigations, it is suggested to analyse a dataset free from the disturbing effect of clouds. Our results confirmed that transmissivity values are more balanced on sunny days, which underpins the necessity of clear days for the more detailed transmissivity investigations focusing on inter-species and canopy-dimensional differences.

The comparison of the results of two A. hippocastanum trees provided information on the effect of dimensional differences (Figure 3; Figure 5, $a$ and $b$ ). In the case of the larger individual the lower transmitted radiation values were associated with reduced transmissivity. One reason for this could be the greater crown volume in the large $A$. hippocastanum individual (Table 1), which implies a longer distance through the canopy that the direct solar beam has to pass, enhanc- ing the foliage absorption therefore lowering $G_{\text {trans }}$. On the other hand, the greater trunk height of the smaller A. hippocastanum specimen (Table 1) connotes that larger amount of diffuse radiation may reach the sensor placed under the tree from lateral directions. Thus, both of these dimensional-related differences allow measuring greater $G_{\text {trans }}$ under the smaller $A$. hippocastanum at the same time of the year, provided that both individuals are healthy (Figure 3; Figure 5, $a$ and $b$ ). Increased transmissivity values were found in the case of the larger A. hippocastanum at the end of the daily measurement period on the investigation days in late summer and autumn (Figure 3). This may be the result of lower sun elevation, cloudy conditions or structural deficiencies at certain parts of the tree crown that increased the value of $G_{\text {trans }}$ (Figure 3). 
The remarkable difference between the median and mean values characterizing the transmissivity of the larger A. hippocastanum is the consequence of the fact that the arithmetical mean is very sensitive to extremes (Table 4) (ANDRAde, H. and Vieira, R. 2007; TAKÁcs, Á. et al. 2015a). Since transmissivity may change rapidly and may show some outlier values depending on the slight movements of leaves because of wind as well as the monotonous change in sun elevation and azimuth, we consider it more appropriate to characterize the distribution of transmissivity with the median value.

The obtained inter-species differences (Figures 2, 4 and 5) in transmissivity may be explained with the characteristics of canopy structure and leaf density (see also SHAHIDAN, M.F. et al. 2010). Due to the dense foliage, there is relatively small and consistent transmitted radiation in the case of T. cordata, which results in small transmissivity values. The good shading potential of Tilia species was also shown by Papp, N. (2013) in Szeged and Konarska, J. et al. (2014) in Gothenburg, Sweden. On the contrary, we found always higher transmissivity values in the case of $S$. japonica due to its sparse canopy allowing direct radiation to reach the instrument more frequently. This attribute is clearly reflected in the fluctuating $G_{\text {trans }}$ and transmissitivity values concerning S. japonica (Figure 2; Figure 5, d).

We consider that the presented measurement method is suitable for gaining generic information about the shading capacity of trees. According to the resulted transmissivity values, the species can be ranked based on their shading capability, and these information are directly usable in the course of green space planning and in selection of appropriate trees.

The obtained results can be used as input data in microclimate simulations to enable more reliable modelling. For example, from the group of tools designed for the assessment of human thermal comfort conditions, SOLWEIG model allows the users to add or change the transmissivity value of the modelled trees. This means that in the course of outdoor space design the effect of altered transmissivity can be evaluated on a territorial basis.

\section{REFERENCES}

Abreu-Harbich, L.V., Labaki, L.C. and Matzarakis, A. 2015. Effect of tree planting design and tree species on human thermal comfort in the tropics. Landscape and Urban Planning 138. 99-109.

Andrade, H. and Vieira, R. 2007. A climatic study of an urban green space: The Gulbenkian park in Lisbon (Portugal). Finisterra 42. 27-46.

Bajsanski, I.V., Milosevic, D.D. and SAVIC, S.M. 2015. Evaluation and improvement of outdoor thermal comfort in urban areas on extreme temperature days: Applications of automatic algorithms. Building and Environment 94. 632-643.

Bowler, D.E., Buyung-Ali, L., Knight, T.M. and Pullin, A.S. 2010. Urban greening to cool towns and cities: A systematic review of the empirical evidence. Landscape and Urban Planning 97. 147-155.

Cantón, M.A., Cortegoso, J.L. and de Rosa, C. 1994. Solar permeability of urban trees in cities of western Argentina. Energy and Buildings 20. 219-230.

Coutts, A.M., White, E.C., Tapper, N.J., Beringer, J. and Livesley, S.J. 2016. Temperature and human thermal comfort effects of street trees across three contrasting street canyon environments. Theoretical and Applied Climatology, DOI 10.1007/s00704-0151409-y.

Dimoudi, A. and Nikolopoulou, M. 2003. Vegetation in the urban environment: microclimatic analysis and benefits. Energy and Buildings 35. 69-76.

Égerházi, L.A., Kovács, A. and Unger, J. 2013. Application of microclimate modelling and onsite survey in planning practice related to an urban micro environment. Advances in Meteorology 2013, Article ID: 251586.

Erell, E., Pearlmutter, D., Boneh, D. and Kutiel, P.B. 2014. Effect of high-albedo materials on pedestrian heat stress in urban street canyons. Urban Climate 10. 367-386.

Gál, T. and Unger, J. 2009. Detection of ventilation paths using high-resolution roughness parameter mapping in a large urban area. Building and Environment 44. 198-206.

Gulyás, Á., Unger, J. and Matzarakis, A. 2006. Assessment of the microclimatic and human comfort conditions in a complex urban environment: modelling and measurements. Building and Environment 41. 1713-1722.

Haase, D., Larondelle, N., Andersson, E., Artmann, M., Borgström, S., Breuste, J., Gomez-BAggethun, E., Gren, A., Hamstead, Z., Hansen, R., Kabisch, N., Kremer, P., Langemeyer, J., Rall, E.L., McPhearson, T., Pauleit, S., Qureshi, S., Schwarz, N., Voigt, A., Wurster, D. and Elmovist, T. 2014. A quantitative review of urban ecosystem service assessments: concepts, models and implementation. Ambio 43. 413-433. 
HMS 2015. Climate characteristics of Szeged. http:// www.met.hu/eghajlat/magyarorszag_eghajlata/varosok_jellemzoi/Szeged/

Jim, C.Y. and CHeN, W.Y. 2008. Assessing the ecosystem service of air pollutant removal by urban trees in Guangzhou (China). Journal of Environmental Management 88. 665-676.

Kántor, N. and Unger, J. 2010. Benefits and opportunities of adopting GIS in thermal comfort studies in resting places: An urban park as an example. Landscape and Urban Planning 98. 36-46.

KÁNTOR, N. and Unger, J. 2011. The most problematic variable in the course of human-biometeorological comfort assessment - the mean radiant temperature. Central European Journal of Geosciences 3. 90-100.

Kántor, N., Kovács, A. and TAKÁcs, Á. 2016. Smallscale human-biometeorological impacts of shading by a large tree. Open Geosciences, in press (DOI 10.1515/geo-2016-0021).

Kirnbauer, M.C., Baetz, B.W. and Kenney, W.A. 2013. Estimating the stormwater attenuation benefits derived from planting four monoculture species of deciduous trees on vacant and underutilized urban land parcels. Urban Forestry E Urban Greening 12. 401-407.

Konarska, J., Lindberg, F., Larsson, A., Thorsson, S. and Holmer, B. 2014. Transmissivity of solar radiation through crowns of single urban trees - application for outdoor thermal comfort modelling. Theoretical and Applied Climatology 117. 363-376.

LeE, H., Holst, J. and Mayer, H. 2013. Modification of human-biometeorologically significant radiant flux densities by shading as local method to mitigate heat stress in summer within urban street canyons. Advances in Meteorology 2013, Article ID 312572.

LeE, H., MAYer, H. and Schindler, D. 2014. Importance of 3-D radiant flux densities for outdoor human thermal comfort on clear-sky summer days in Freiburg, Southwest Germany. Meteorologische Zeitschrift 23. 315-330.

Lelovics, E., Unger, J., Gál, T. and Gál, C.V. 2014. Design of an urban monitoring network based on Local Climate Zone mapping and temperature pattern modelling. Climate Research 60. 51-62.

Mayer, H., Holst, J., Dostal, P., Imbery, F. and Schindler, D. 2008. Human thermal comfort in summer within an urban street canyon in Central Europe. Meteorologische Zeitschrift 17. 241-250.

Mullaney, J., Lucke, T. and Trueman, S.J. 2015. A review of benefits and challenges in growing street trees in paved urban environment. Landscape and Urban Planning 134. 157-166.

NG, E. 2009. Policies and technical guidelines for urban planning of high-density cities - air ventilation assessment (AVA) of Hong Kong. Building and Environment 44. 1478-1488.
Nowak, D.J., Greenfield, E.J., Hoehn, R.E. and LAPoint, E. 2013. Carbon storage and sequestration by trees in urban and community areas of the United States. Environmental Pollution 178. 229-236.

Papp, N. 2013. A városi fás vegetáció hatása a termikus komfortviszonyokra Szeged példáján (The impact of urban woody vegetation on thermal comfort conditions through the example of Szeged). MS Thesis, Szeged, University of Szeged, $69 \mathrm{p}$.

Pongrácz, R., Bartholy, J. and Bartha, E.B. 2013. Analysis of projected changes in the occurrence of heat waves in Hungary. Advences in Geosciences 35. 115-122.

Shahidan, M.F., Shariff, M.K.M., Jones, P., Salleh, E. and Abdullah, A.M. 2010. A comparison of Mesua ferrea L. and Hura crepitans L. for shade creation and radiation modification in improving thermal comfort. Landscape and Urban Planning 97. 168-181.

Sun, R. and CHEN, L. 2012. How can urban water bodies be designed for climate adaptation? Landscape and Urban Planning 105. 27-33.

TAKÁcs, Á., Kiss, M., Gulyás, Á. and Kántor, N. 2015a. Microclimate regulation potential of different tree species: transmissivity measurements in Szeged, Hungary. $9^{\text {th }}$ International Conference on Urban Climate, Toulouse, 544, 6 p.

TAKÁcs, Á., Kiss, M., Kántor, N. and Gulyás, Á. 2015b. A városi fás vegetáció humán bioklimatológiai jelentősége - gyakori szegedi fafajok árnyékhatásának vizsgálata (The human bioclimatic significance of urban woody vegetation - investigation of the shading effect of frequent tree species in Szeged). In Spring Wind 2015. Conference book. Ed.: Keresztes, G. Eger-Budapest, Doktoranduszok Országos Szövetsége, 571-587.

TAKács Á, Kiss, M., Gulyás, Á., Tanács, E. and KÁntor, N. 2016a. Solar permeability of different tree species in Szeged, Hungary. Geographica Pannonica 20. 32-41.

TAKÁcs, Á., Kiss, M., Hof, A., Tanács, E., Gulyás, Á. and KÁntor, N. 2016b. Microclimate modification by urban shade trees - an integrated approach to aid ecosystem service based decision-making. Procedia Environmental Sciences 3. 97-109. (Article reference: PROENV3012).

Thorsson, S., Rocklöv, J., Konarska, J., LindberG, F., Holmer, B., Dousset, B. and Rayner, D. 2014. Mean radiant temperature - A predictor of heat related mortality. Urban Climate 10. 332-345.

UN 2014. World Urbanization Prospects: The 2014 Revision, Highlights (ST/ESA/SER.A/352). New York, United Nations, $32 \mathrm{p}$.

YAnG, X., Zhao, L., Bruse, M. and Meng, Q. 2013. Evaluation of a microclimate model for predicting the thermal behavior of different ground surfaces. Building and Environment 60. 93-104. 


\title{
Changing Ethnic Patterns of the Carpatho-Pannonian Area from the Late $15^{\text {th }}$ until the Early $21^{\text {st }}$ Century
}

\author{
Edited by: KÁROLY KOCSIS and PATRIK TÁTRAI \\ Hungarian Academy of Sciences, Research Centre for Astronomy and Earth Sciences \\ Budapest, 2015
}

This is the third, revised and enlarged edition of the Changing Ethnic Patterns of the Carpatho-Pannonian Area. The work is georeferenced and comes with a CD-appendix. The collection of maps visually presents the ethnic structure of the ethnically, religiously and culturally unique and diverse Carpathian Basin and its neighbourhood, the Carpatho-Pannonian area. The volume - in Hungarian and English - consists of three structural parts. On the main map, pie charts depict the ethnic structure of the settlements in proportion to the population based on the latest census data. In the supplementary maps, changes in the ethnic structure can be seen at ten points in time (in 1495, 1784, 1880, 1910, 1930, 1941, 1960, 1990, 2001 and 2011). The third part of the work is the accompanying text, which outlines ethnic trends in the past five hundred years in the studied area. This volume presents the Carpatho-Pannonian area as a whole. Thus, the reader can browse the ethnic data of some thirty thousand settlements in various maps.

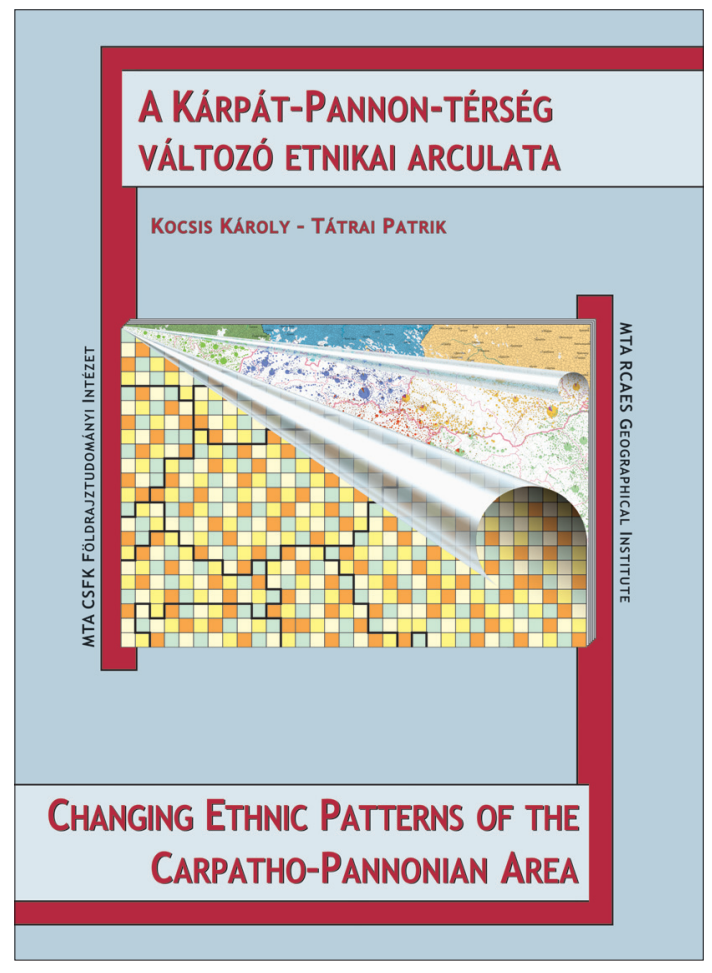

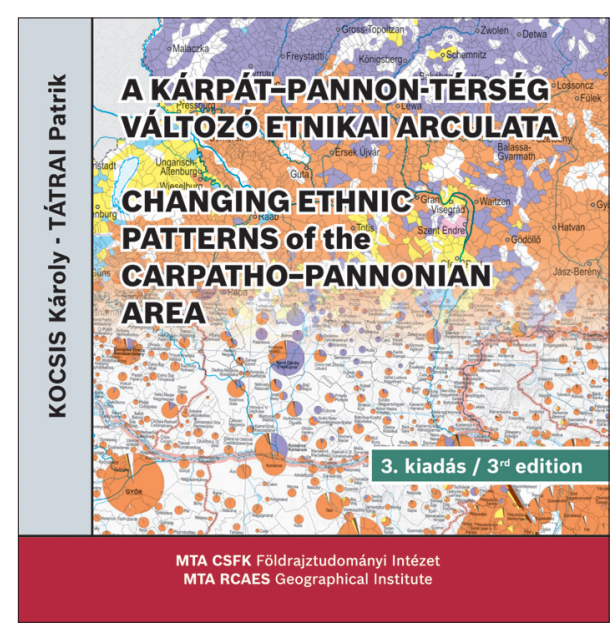

Price: EUR 12.00

Order: Geographical Institute RCAES MTA Library. H-1112 Budapest, Budaörsi út 45.

E-mail: magyar.arpad@csfk.mta.hu 